\title{
Telomeropathies - A Genetic Conglomerate
}

\section{Gurpreet Kaur, Priyanka Mishra, Preeti Tripathi*, Seema Tyagi, Haraprasad Pati and Manoranjan Manapara}

Department of Hematopathology, Command Hospital Airforce, Bangalore, India

*Corresponding Author: Preeti Tripathi, Department of Hematopathology,

Command Hospital Airforce, Bangalore, India.
Received: February 16, 2021

Published: March 20, 2021

(C) All rights are reserved by Preeti Tripathi., et al.

\section{Abstract}

Telomeres are repeated TTAGGG hexanucleotides and proteins associated with them. Telomeres function to form a stable end of the chromosome and protect it from being recognized as a DNA fragment that needs repair. Telomeropathies or 'telomere biology disorders' are rare and heterogenous diseases that are caused by mutations in the maintenance of telomerase or the damage response system (DDR). Telomeropathies or telomere biology disorders (TBDs) may be classified as primary and secondary. Primary telomeropathies are due to defects in the telomere maintenance machinery whereas secondary telomeropathies are caused by failures in the DDR.

Dyskeratosis congenita (DKC) which is an inherited bone marrow failure syndrome is the classical example of the telomeropathy syndromes. Progressive telomere loss or attrition is associated with and is likely to be an etiology of malignant transformation. Over $85 \%$ of malignant tumors show positivity for telomerase, in contrast most normal tissues are telomerase-negative, and owing to this telomerase enzyme has become an excellent target in research for newer therapies that inhibit telomerase and shorten telomeres in malignant cells. In aplastic anemia, patients with the shortest telomeres are four- to five times more likely to have clonal evolution of disease and undergo progression to myelodysplastic syndrome and leukemia. The telomeropathies hence resemble a spectrum of disorders rather than being distinct diseases.

Diagnosis of a telomeropathies needs awareness with regards to the clinical features the laboratory results and the molecular testing. Due to the rarity of telomeropathies and a low degree of suspicion the diagnosis may often be missed. For some telomeropathies early diagnosis will translate into overall survival benefits and improved quality of life. In this review, we give an overview of the pathophysiology, signs and symptoms of the disorders caused by defects in telomere biology and touch upon the detection of telomeropathies in the laboratory.

Keywords: Telomeres; Telomerase Complex; Dyskeratosis Congenita; Telomere Length; Flow-FISH

\section{Introduction}

Telomeropathies or 'telomere biology disorders' (TBD) are a group of rare genetic disorders caused by defects in the maintenance of the telomerase complex along with the DNA damage response sensing mechanisms. As the cell ages there is progressive loss of telomeres with every cycle of replication. This loss is however harmless as these are non coding regions. Besides ageing environmental factors such as oxidative damage and regenerative 
stress can also lead to shortening. Critical shortening leads to senescence, apoptosis, or, rarely malignant transformation. The progressive shortening of telomeres is counteracted by the telomerase enzyme that extends telomerases. When cell division continues despite critically short telomeres this protective function is gradually lost.

The association of Telomeres and bone marrow failure was postulated after identifying shortening of telomeres in the leukocytes of acquired AA patients [1,2].

Thereafter followed the correlation shortened telomeres were the genetic caused of inherited aplastic anemia or Dyskeratosis congenita [3]. Progressive telomeres loss is an explanation for the 'Hayflick limit' a concept that explains the mechanisms underlying cellular aging. This concept states that a normal human cell after forty to sixty divisions break down by programmed cell death or apoptosis as it cannot divide beyond this limit Somatic cells such as lymphocytes have telomeric DNA ranging from 8 to 14 kilobases $(\mathrm{kb})$ at birth, 50 to 100 base pairs of this DNA is removed per cell division. The normal rate of telomere shortening in normal individuals is approx $60 \mathrm{bp} / \mathrm{yr}$ whereas in telomere disorders it increases to approximately $120 \mathrm{bp} / \mathrm{yr}$ [4-6].

\section{TELOMERES - The normal biology}

Telomeres are nucleoproteins, and their DNA consists of repetitive sequences, TTAGGG in humans. Telomeres are formed by a 30- to 400-nucleotide long overhang of a guanosine-rich strand, also known as the G-strand overhang which folds back to a double-stranded area forming a T-loop and a displacement or D-loop. Telomerase is a ribonucleoprotein enzyme complex that synthesizes telomeres.

The Telomerase complex includes-

- Telomerase: a reverse transcriptase (encoded by the gene TERT).

- A RNA template (encoded by TERC), and

- Associated proteins that affect assembly, trafficking, recruitment of telomerase to telomeres, and stability of telomerase, a number of accessory proteins including dyskerin, NHP2,NOP10, and GAR1.

Telomeres on are flanked by special regions, called the shelterin complex that regulate telomere lengths and protect them from DNA damage response. The shelterin complex is a 6-protein complex - telomeric repeat binding factors 1 and 2 (TRF1, TRF2) TRF1-interacting protein 2(TIN2) protection of telomeresProtein1 (POT1) POT1-interacting protein (TPP1) and repressor activator protein 1(RAP1) as shown in figure 1 [8].

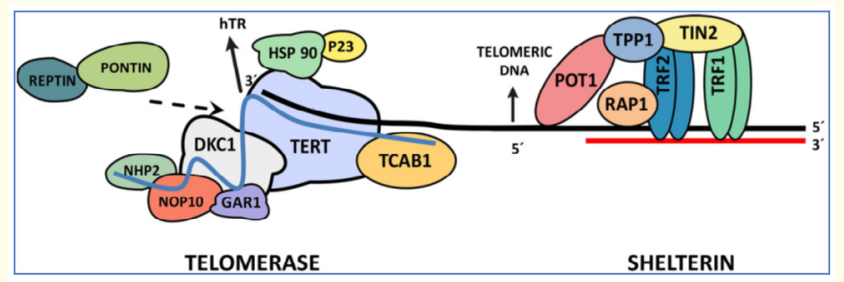

Figure 1: Schematic representation of the telomere/telomerase complex. In black we found the telomeric DNA overhang. In red the telomere and in light blue the hTR component of telomerase. Telomerase is represented in the left, showing the different constitutive elements to have an active telomerase. $\mathrm{T}$ elomere is represented at the right with the six proteins that constitute the shelterin complex (Adapted from Armando RG,

Mengual Gomez DL, Maggio J, Sanmartin MC, Gomez DE.

Telomeropathies: Etiology, diagnosis, treatment and follow-up.

Ethical and legal on side rations. Clin Genet. 2019 Jul;

$$
\text { 96(1):3-16. [22]. }
$$

The gene coding for human TERC maps to chromosome $3 q$ and comprises of 451 nucleotides, which includes a 11 bp long RNA template (50-CUAACCCUAAC-30) complementary to human telomere repeats (TTAGGG).

While TERC can be found in abundance in tumor and non-tumor cells, the catalytic subunit TERT is expressed increasingly in cells with self-renewal capacity such as hematopoietic stem and progenitor cells (HSPCs), proliferating lymphocytes and the regenerating cells in the basal layer of the epidermis [9].

The other associated proteins include dyskerin, NHP2 (nuclear protein family A, member 2), NOP10 (nuclear protein family A, member3), NAF1 (nuclear assembly factor 1), and GAR1 (nuclear protein family A, member 1 ). These proteins help to recruiting, trafficking and stability of the telomerase complex. If telomeres lack shelterin, the extreme end of telomeres are recognized as double 
strand breaks (DSB) p53 is activated and this leading to apoptosis senescence or both. This forms an integral part of the DNA damage response pathway.

Part of the mechanism by which telomere ends are hidden is via a structure known as a T-loop; During DNA replication owing to the action of RTEL1 or other helicases the T loop dissociates and further excision of The T-loop occurs by the SLX4 nuclease leading to rapid telomere loss.

\section{Telomeropathies and their pathogenesis}

The pathogenesis of telomere biology disorders includes decreased telomerase activity the most common mechanism of which is TERT, TERC, DKC1, NHP2, NOP10, and NAF1 mutations leading to decreased telomerase levels or activity. There can be impaired telomerase recruitment to telomeres due to defective TCAB1. Impaired telomere duplication and impaired regulation of the telomere biology related gene transcripts involving the CST complex are other causes for impaired function [10]. These candidate genes associated process and the diseases resulting thereof are depicted in table 1.

There are a few additional factors and these include TRF1 and TRF2-associated factors, such as Apollo, MRN complex, PNUTS, MCPH1, WRN/FEN1, TNKS and the ORC complex TERRA. These have a variety of functions including telomere maintenance, response to certain types of DNA damage; regulation of telomere length and protecting telomeres from DNA repair [11].

\section{Dyskeratosis congenita- The prototype Telomeropathy}

DC is the second most common type of inherited bone marrow failure syndromes (IBMFS) and is named after its clinical manifestation of ectodermal dysplasia, a triad of oral leukoplakia dystrophic nails, skin hyperpigmentation. DC was initially described by Zinsser and was recognized as a clinical entity by Engman and Cole $[12,13]$.

Three different inheritance patterns have been described in DC: X-linked, autosomal dominant (AD), and autosomal recessive. In large registries, the most common inheritance pattern reported is X-linked, affecting the DKC1 gene, which encodes dyskerin, a component of the telomerase complex. The clinical features in DC present early in childhood. Skin pigmentation and nail dystrophy appear first, usually by the first decade of life. Hyper- or hypopig-

\begin{tabular}{|c|c|c|}
\hline $\begin{array}{l}\text { Candidate } \\
\text { gene }\end{array}$ & Process/complex & Diseases \\
\hline TIN2 & $\begin{array}{l}\text { Forms Shelterin complex } \\
\text { inhibits TRF1 PARsylation }\end{array}$ & $\begin{array}{l}\text { DKC, } \\
\text { Revesz } \\
\text { syndrome, } \\
\text { HHS }\end{array}$ \\
\hline RTEL1 & $\begin{array}{l}\text { Associated with T-loop } \\
\text { dissociation, target of } \\
\text { cytosolic iron-sulfur protein } \\
\text { assembly (CIA) complex }\end{array}$ & DKC/HHS \\
\hline CTC1 & Associated with CST complex & $\begin{array}{l}\text { Coats plus } \\
\text { syndrome }\end{array}$ \\
\hline Apollo & Overhang processing & HHS \\
\hline $\begin{array}{l}\text { TERT, } \\
\text { TERC, } \\
\text { Dyskerin, } \\
\text { NHP2, } \\
\text { NOP10 }\end{array}$ & Form the Telomerase complex & $\begin{array}{c}\text { DKC, aplastic } \\
\text { anemia } \\
\text { IPF }\end{array}$ \\
\hline TCAB1 & $\begin{array}{l}\text { Cajal body, } \\
\text { telomerase assembly }\end{array}$ & DKC \\
\hline
\end{tabular}

Table 1: Genes and their respective complexes in telomere biology disorders.

mentation of tan-to-gray colour can be seen which on Histopathology presents as Poikilodermatous changes with an atrophic and telangiectatic epidermis. Ectodermal abnormalities such as alopecia of the scalp, eyebrows, and eyelashes; premature graying hair; hyperhidrosis; hyperkeratosis of the palms and soles; and adermatoglyphia (loss of dermal ridges on fingers and toes) are commonly encountered. BM failure usually develops below the age of 20 years. Macrocytosis with or without anemia is common in the telomeropathies. Over patients $90 \%$ have peripheral cytopenias by the third decade of life. The bone marrow in such patients may be indistinguishable from acquired aplastic anaemia [14].

$80 \%$ cases have underlying pulmonary complications, including fibrosis and abnormalities of pulmonary vasculature. On high resolution computerized tomography patchy, basal, and peripheral reticular opacities, ground glass opacities, and honey combing is seen. Bronchiolitis obliterans organizing pneumonia, chronic hypersensitivity pneumonitis, emphysema alone, or combined pulmonary fibrosis and emphysema can also be seen $[15,16]$. Hepatic involvement in telomere diseases may show changes related to cir- 
rhosis, portal hypertension, or steatosis. Presence of both pulmonary fibrosis and bone marrow failure is highly specific for an underlying telomere biology disorder [17]. Esophageal and lacrimal duct stenosis, enteropathy, enterocolitis, osteoporosis, avascular necrosis, and immunodeficiency have been described [18].

The main causes for mortality include bone marrow failure and immunodeficiency (60-70\%), pulmonary complications $(\sim 10-$ $15 \%)$ and cancers ( 10\%) [14].

Owing to the association of DKC and its more severe variants with underlying malignant transformation these patients should undergo annual health checkups and avoid alcohol, sun exposure, smoking etc.

\section{Severe forms of DC- These include the following variants}

Hoyeraal-Hreidarsson syndrome

Hoyeraal-Hreidarsson syndrome (HHS) with a path gnomonic cerebellar hypoplasia is a serious and extremely rare presentation of DC. It has an X linked recessive inheritance. Clinical features include intrauterine growth retardation bone marrow failure, immunodeficiency and microcephaly. So far only about 50 cases have been described in literature. HHS-causing mutations have been found in TRF1, TIN2 and RTEL1 genes. The RTEL gene encodes the helicases that unwinds the Tloop [19].

\section{Revesz syndrome}

Revesz syndrome (RS) is defined by symptoms of HHS along with prominent exudative retinopathy which characterizes this syndrome. The mode of inheritance is autosomal dominant and the underlying mutation is in the TINF2 gene.

Coats plus syndrome- Cerebroretinal microangiopathy with calcifications and cysts

This resembles Revesz but cerebellar and hematologic manifestations are less prominent. It is due to compound heterozygous mutations in CTC1 [20].

\section{Secondary telomeropathies}

The secondary telomeropathies are disorders which have an underlying telomeropathy but whether this is a primary driver of disease or acts just as a catalyst is yet to be known [21]. These are briefly described in the table below in table 2 .

\begin{tabular}{|c|c|c|c|}
\hline Disease & Inheritance & Genes & $\begin{array}{c}\text { Salient } \\
\text { features }\end{array}$ \\
\hline $\begin{array}{l}\text { Aplastic } \\
\text { anemia }\end{array}$ & $\mathrm{AD}$ & $\begin{array}{c}\text { Telomerase core } \\
\text { components: } \\
\text { TERT } \\
\text { TERC }\end{array}$ & $\begin{array}{c}\text { Symptoms } \\
\text { of marrow } \\
\text { failure }\end{array}$ \\
\hline $\begin{array}{l}\text { Fanconi } \\
\text { anemia }\end{array}$ & $\begin{array}{l}\text { X-LR } \\
\text { AR } \\
\text { AD } \\
\text { AR }\end{array}$ & $\begin{array}{c}\text { Telomerase } \\
\text { biogenesis: } \\
\text { DKC1 } \\
\text { NOP10 } \\
\text { NHP2 } \\
\text { Shelterin c } \\
\text { omponents } \\
\text { ACD } \\
\text { FANCD2 }\end{array}$ & \\
\hline $\begin{array}{l}\text { Idiopathic } \\
\text { pulmo- } \\
\text { nary } \\
\text { fibrosis }\end{array}$ & $\mathrm{AD}$ & $\begin{array}{c}\text { Telomerase core } \\
\text { components: } \\
\text { TERC } \\
\text { TERT } \\
\text { Telomerase } \\
\text { biogenesis: } \\
\text { NAF1 }\end{array}$ & $\begin{array}{c}\text { Bronchiolitis } \\
\text { obliterans } \\
\text { with } \\
\text { organizing } \\
\text { pneumonia, } \\
\text { chronic } \\
\text { hypersensitiv- } \\
\text { ity pneumo- } \\
\text { nitis, } \\
\text { interstitial } \\
\text { pneumonitis, } \\
\text { and } \\
\text { emphysema } \\
\text { familial } \\
\text { interstitial } \\
\text { pneumonia }\end{array}$ \\
\hline $\begin{array}{l}\text { Crypto- } \\
\text { genic } \\
\text { cirrhosis } \\
\text { or } \\
\text { nodular } \\
\text { regen- } \\
\text { erative } \\
\text { hyperpla- } \\
\text { sia }\end{array}$ & $\mathrm{AD}$ & $\begin{array}{c}\text { Telomerase core } \\
\text { components: } \\
\text { TERT } \\
\text { TERC }\end{array}$ & $\begin{array}{c}\text { Hepatic } \\
\text { parenchymal } \\
\text { inflamma- } \\
\text { tion, hepatic } \\
\text { fibrosis, } \\
\text { cryptogenic } \\
\text { cirrhosis } \\
\text { of the liver, } \\
\text { nodular } \\
\text { regenerative } \\
\text { hyperplasia, } \\
\text { and portal } \\
\text { hypertension }\end{array}$ \\
\hline
\end{tabular}




\begin{tabular}{|c|c|c|c|}
\hline $\begin{array}{l}\text { Roth- } \\
\text { mund- } \\
\text { Thomson } \\
\text { syndrome }\end{array}$ & AR & RECQL4 & \\
\hline $\begin{array}{l}\text { Immu- } \\
\text { nodefi- } \\
\text { ciency, } \\
\text { centro- } \\
\text { meric } \\
\text { region } \\
\text { instability } \\
\text { and facial } \\
\text { anomalies } \\
\text { type } 1\end{array}$ & AR & DNMT3B & $\begin{array}{l}\text { Dimorphism } \\
\text { in the middle } \\
\text { portion of the } \\
\text { face, growth } \\
\text { retardation } \\
\text { and } \\
\text { a psychomo- } \\
\text { tor } \\
\text { retardation } \\
\text { senescence of } \\
\text { B and T } \\
\text { lymphocytes } \\
\text { and a } \\
\text { spectrum of } \\
\text { immune } \\
\text { defects }\end{array}$ \\
\hline $\begin{array}{l}\text { Baller- } \\
\text { Gerold } \\
\text { syndrome }\end{array}$ & & $\begin{array}{c}\text { RECQL4, FGFR2, } \\
\text { TWIST }\end{array}$ & $\begin{array}{c}\text { Coronal } \\
\text { craniosynos- } \\
\text { tosis } \\
\text { with radial } \\
\text { ray } \\
\text { anoma- } \\
\text { lies, facial } \\
\text { dimorphism, } \\
\text { delayed } \\
\text { growth }\end{array}$ \\
\hline $\begin{array}{l}\text { Bloom } \\
\text { syndrome }\end{array}$ & $\begin{array}{c}\text { Autosomal } \\
\text { recessive }\end{array}$ & BLM & $\begin{array}{c}\text { Dolichocepha- } \\
\text { lism, } \\
\text { a narrow face, } \\
\text { a prominent } \\
\text { nose and ears } \\
\text { and } \\
\text { mandibular } \\
\text { hypoplasia, } \\
\text { facial } \\
\text { telangiectasia, } \\
\text { low white } \\
\text { blood cell } \\
\text { count and } \\
\text { progressive } \\
\text { lung disease }\end{array}$ \\
\hline $\begin{array}{l}\text { Xero- } \\
\text { derma } \\
\text { pigmen- } \\
\text { tosum }\end{array}$ & AR & $\begin{array}{c}\text { XPC, DDB2, } \\
\text { ERCC2, EERCC3, } \\
\text { ERCC4, ERCC5, } \\
\text { POLH and XPA }\end{array}$ & $\begin{array}{l}\text { Premature } \\
\text { ageing, } \\
\text { cutaneous } \\
\text { cancer, } \\
\text { neurological } \\
\text { manifesta- } \\
\text { tions } \\
\text { propensity to } \\
\text { cancer }\end{array}$ \\
\hline
\end{tabular}

\begin{tabular}{|c|c|c|c|}
\hline $\begin{array}{l}\text { Trichot- } \\
\text { hiodys- } \\
\text { trophy }\end{array}$ & & $\begin{array}{l}\text { ERCC2 ( most } \\
\text { frequent) } \\
\text { TTD2, ERCC3/ } \\
\text { XPB, GTF2H5, } \\
\text { MPLKI, } \\
\text { RNF113A }\end{array}$ & $\begin{array}{l}\text { Brittle fragile } \\
\text { hair, often } \\
\text { combined } \\
\text { growth } \\
\text { retardation } \\
\text { intellectual } \\
\text { deficit, } \\
\text { congenital } \\
\text { ichthyosis, } \\
\text { ocular and } \\
\text { nail } \\
\text { abnormalities, } \\
\text { short stature, } \\
\text { frequent } \\
\text { infections, } \\
\text { infertility }\end{array}$ \\
\hline $\begin{array}{l}\text { Cockayne } \\
\text { syndrome }\end{array}$ & AR & $\begin{array}{c}\text { ERCC6(most } \\
\text { common) } \\
\text { (CSA, CSB, XPB, } \\
\text { XPD and XPG }\end{array}$ & $\begin{array}{l}\text { Growth fail- } \\
\text { ure, prema- } \\
\text { ture aging, } \\
\text { photosen- } \\
\text { sitivity, } \\
\text { progressive } \\
\text { neurological } \\
\text { dysfunction }\end{array}$ \\
\hline $\begin{array}{l}\text { Seckel } \\
\text { syndrome }\end{array}$ & AR & ATR & $\begin{array}{c}\text { microcephalic } \\
\text { primordial } \\
\text { dwarfism, } \\
\text { dysmorphic } \\
\text { face, } \\
\text { clinodactyly }\end{array}$ \\
\hline $\begin{array}{l}\text { Ataxia } \\
\text { telangiec- } \\
\text { tasia }\end{array}$ & & ATM kinase & $\begin{array}{c}\text { Staggering } \\
\text { gait, muscular } \\
\text { incoordina- } \\
\text { tion, } \\
\text { immunodefi- } \\
\text { ciency, } \\
\text { neurodegen- } \\
\text { eration } \\
\text { and prema- } \\
\text { ture aging, } \\
\text { increased } \\
\text { occurrence of } \\
\text { malignancy }\end{array}$ \\
\hline $\begin{array}{l}\text { Fa- } \\
\text { cioscapu- } \\
\text { lohumeral } \\
\text { muscular } \\
\text { dystrophy }\end{array}$ & $\begin{array}{c}\text { Autosomal } \\
\text { dominant }\end{array}$ & DUX4 & \\
\hline
\end{tabular}

Table 2: The secondary telomeropathies their inheritance pattern and salient features. 
Diagnosis of telomere biology disorderss

Detection of a telomere disease requires awareness with regards to the clinical features the laboratory testing and subsequent genetic testing. Due to the rarity of telomeropathies and a low degree of suspicion the diagnosis may often be missed Several methods are available for measuring the length of telomere repeats of these available methods analysis of terminal restriction fragment (TRF) length by Southern blot analysis is the gold standard. However, this method overestimates the telomere length by several $\mathrm{kb}$ because the distance between terminal restriction sites in the genomic DNA and the actual telomeres varies between chromosomes. The TRF method is advantageous in being reproducible however it needs large amounts of DNA and takes a longer time. The PCR based methods that are available measure either average or chromosome specific length. Measuring the average chromosome length provides a measure of telomere DNA in relation to the germline DNA (usually a single-copy gene) as a single ratio value whereas measuring chromosome specific length gives information on the actual length of telomere repeats at a specified chromosome $\operatorname{arm}[23,24]$.

Fluorescence in situ hybridization of telomere repeats measured by flow cytometry (flow-FISH) is a quick, relatively inexpensive technique to measure telomere length. It was first described as a modification of Q FISH (quantitative) by Rufer., et al. in 1998 [25]. The underlying principle of Q FISH is that at low ionic strength the peptide nucleic acids (PNA) can anneal to complementary single stranded DNA sequences while single stranded DNA sequences cannot. Quantitative hybridization to telomere repeats is achieved using conditions that only allow labeled (CCCTAA) PNA to hybridize to (TTAGGG) target sequences. Flow FISH is essentially is the combination of flow cytometry with cytogenetics. The mean telomere length in lymphocytes by flow-FISH if less than the first percentile when compared with age-matched controls accurately identifies patients with telomerase gene mutations. Flow FISH involves six basic steps of cell separation, DNA denaturation, hybridization with PNA probe, a washing step to remove excess probe, DNA counterstaining and finally acquisition and analysis. Sample is collected in sodium heparin or EDTA or citrate vacutainer tubes and is processed within 24-48 hrs. Single-cell suspensions of cow thymocytes are used as internal control. White blood cells are purified or separated by osmotic lysis of RBCs with NH4Cl. A high con- centration of RBCs or hemoglobin (corresponding to a haematocrit of more than $2 \%$ ) interferes with telomere fluorescence measurements by quenching of the relatively weak FITC fluorescence of the telomere probe. Bovine thymocytes are used as internal control, and the telomere length in bovine thymocytes is about 2-3 times longer than that in human cells. The adavantage of Flow FISH is that it and determine mean 'length "for specific cell populations, can provide cell type specific information and can be automated. Samples with relatively low cell counts $\left(10^{5}\right)$ can be processed. Minimum detectable difference in telomere length is in range of 0.2 to $0.5 \mathrm{~kb}$. The disadvantages are that it is labour intensive, requires highly skilled labour and telomere length expressed as relative fluorescence unit $[2,26]$.

\section{Conclusion}

The telomeropathies, especially when they are mild or occur in a chronic form may be misdiagnosed or may go unrecognised. Therefore, a high degree of suspicion is essential on the part of the treating clinicians. The association of telomerase mutations with disease in three separate organ systems - the lungs, the liver and the bone marrow has important consequences for the patients and the treating physician. In the family history, attention should be paid to even mild blood count abnormalities in relatives, as well as more severe hematologic disease, especially acute myeloid leukemia. In other organ systems, usually neglected in a standard history, pulmonary fibrosis and hepatic cirrhosis are important clues to the diagnosis of a telomeropathy. If treatment protocols for the TBD are available then these schemes and updated recommendations should be followed if already available and any new therapies or clinical studies should be kept in mind. If the disease does not have a cure preventive care strategy, symptomatic treatment, screening for potential complications and supportive treatment should be given [22].

The importance of telomeres in repair and regeneration with regards to fibrogeneis and adipogenesis may be of particular interest. Telomere attrition linking chronic inflammation and carcinogenesis may be a pathway that could modulated by drugs or hormones that maintain or elongate telomeres. Explanations for variations in the genotype and phenotype, high degree of variable penetrance, organ specific involvement, and clinical course are still missing and are areas of potential research. 


\section{Bibliography}

1. Ball SE., et al. "Progressive telomere shortening in aplastic anemia”. Blood 91.10 (1998): 3582-3592.

2. Brummendorf TH., et al. "Telomere length in leukocyte subpopulations of patients with aplastic anemia". Blood 97.4 (2001): 895-900.

3. Heiss NS., et al. "X-linked dyskeratosis congenita is caused by mutations in a highly conserved gene with putative nucleolar functions". Nature Genetics 19.1 (1998): 32-38.

4. Townsley DM., et al. "Danazol Treatment for Telomere Diseases". The New England Journal of Medicine 374.20 (2016): 1922-1931.

5. De Lange T. "Shelterin: The protein complex that shapes and safeguards human telomeres". Genes Development 19 (2005): 2100-2110.

6. Yamaguchi H., et al. "Mutations in TERT, the gene for telomerase reverse transcriptase, in aplastic anemia". The New England Journal of Medicine 352 (2005): 1413-1424.

7. Harley CB and Kim NW. "Telomerase and cancer". Important Advances in Oncology (1996): 57-66.

8. Shay JW and Roninson IB. "Hallmarks of senescence in carcinogenesis and cancer therapy". Oncogene 23 (2004): 29192933.

9. Armanios M and Blackburn EH. "The telomeresyndromes". Nature Reviews Genetics 13.10 (2012): 693-704.

10. Zvereva MI., et al. "Telomerase: structure, functions, and activity regulation". Biochemistry (Mosc). 75.13 (2010): 1563-1583.

11. Collins K and Mitchell JR. "Telomerase in the human organism'. Oncogene 21 (2002): 564-579.

12. Engman MA. "A unique case of reticular pigmentation of the skin with atrophy". Archiv für Dermatologie und Syphilis 13 (1926): 685-687.

13. Cole H., et al. "Dyskeratosis congenita with pigmentation, dystrophia unguis and leukokeratosis". Archiv für Dermatologie und Syphilis 21 (1930): 71-95.

14. Vulliamy TJ., et al. "Mutations in dyskeratosis congenita: their impact on telomere length and the diversity of clinical presentation". Blood 107.7 (2006): 2680-2685.

15. Diaz de Leon A., et al. "Telomere lengths, pulmonary fibrosis andtelomerase (TERT) mutations". PLoS ONE 5.5 (2010): e10680.

16. Diaz de Leon A., et al. "Subclinical lung disease, macrocytosis, and premature graying in kindreds with telomerase (TERT) mutations". Chest 140.3 (2011): 753-763.

17. Calado RT., et al. "A spectrum of severe familial liver disorders associate with telomerase mutations". PLOS ONE 20094 (11): e7926.

18. Jonassaint NL., et al. "The gastrointestinal manifestations of telomere-mediated disease". Aging Cell 12.2 (2013): 319-323.

19. Glousker G., et al. "Unraveling the pathogenesis of HoyeraalHreidarsson syndrome, a complex telomere biology disorder". British Journal of Haematology 170.4 (2015): 457-471.

20. Revesz T., et al. "Bilateral retinopathy,aplasticanaemia, and central nervous system abnormalities: a newsyndrome?" Journal of Medical Genetics 29.9 (1992): 673-675.

21. Linnankivi T., et al. "Cerebroretinal microangiopathy with calcifications and cysts". Neurology 67.8 (2006): 1437-1443.

22. Armando RG., et al. "Telomeropathies: Etiology, diagnosis, treatment and follow-up. Ethical and legal considerations". Clinical Genetics 96.1 (2019): 3-16.

23. Cawtho RM., et al. "Association between telomere length in blood and mortality in people aged 60years or older". Lancet 361 (2003): 393-395.

24. Baird DM., et al. "Extensive allelic variation and ultrashort telomeres in senescent human cells". Nature Genetics 33 (2003): 203-207.

25. Rufer N., et al. "Methods for the ex vivo characterization of human CD8+ T subsets based on gene expression and replicative 
history analysis". Methods in Molecular Medicine 109 (2005):

265-284.

26. Baerlocher GM., et al. "Telomere length measurement by fluorescence in situ hybridization and flow cytometry: tips and pitfalls". Cytometry 47 (2002): 89-99.

\section{Assets from publication with us}

- Prompt Acknowledgement after receiving the article

- Thorough Double blinded peer review

- Rapid Publication

- Issue of Publication Certificate

- High visibility of your Published work

Website: www.actascientific.com/

Submit Article: www.actascientific.com/submission.php

Email us: editor@actascientific.com

Contact us: +919182824667 